\begin{tabular}{l|l}
$\mathbf{m}$ & south \\
$\mathbf{m} \boldsymbol{n}$ & asia
\end{tabular}

samaj multidisciplinary

uing academic

III journat
South Asia Multidisciplinary Academic Journal

$12 \mid 2015$

On Names in South Asia: Iteration, (Im)propriety and Dissimulation

\title{
Badnam Science? The Spectre of the 'Bad' Name and the Politics of Stem Cell Science in India
}

\section{Aditya Bharadwaj}

\section{(2) OpenEdition}

\section{Journals}

Electronic version

URL: http://journals.openedition.org/samaj/3999

DOI: 10.4000/samaj.3999

ISSN: $1960-6060$

Publisher

Association pour la recherche sur l'Asie du Sud (ARAS)

Electronic reference

Aditya Bharadwaj, «Badnam Science? The Spectre of the 'Bad' Name and the Politics of Stem Cell Science in India », South Asia Multidisciplinary Academic Journal [Online], 12 | 2015, Online since 15 October 2015, connection on 19 April 2019. URL : http://journals.openedition.org/samaj/3999 ; DOI : 10.4000/samaj.3999

This text was automatically generated on 19 April 2019

This work is licensed under a Creative Commons Attribution-NonCommercial-NoDerivatives 4.0 International License. 


\title{
Badnam Science? The Spectre of the 'Bad' Name and the Politics of Stem Cell Science in India
}

\author{
Aditya Bharadwaj
}

\section{AUTHOR'S NOTE}

The data in this article is drawn from a larger research project supported by the European Research Council (ERC), Grant Number 313769. I am grateful to the specialissue's editors, Veena Das and Jacob Copeman, for their truly helpful and inspiring comments. I also thank the three anonymous referees for their careful reading and comments.

'A rose by any other name would smell as sweet'

(William Shakespeare)

1 Badnam is a demolished name. Badnami is the soiled remnants, debris, of a name pulled down. Names can implode with projectile ferocity, decimating immediate surroundings and reverberating much further. The debris or detached broken remnants of a once 'solid name' can possess the shrapnel-like intensity that revolves around a spoiled name. However, proximity to the shards of an imploded name can be an opportunity as well as a danger. We can say that the powerful gravitational force of an annihilated name can pull within its ambit proximate and distant names and reputations, with unpredictable consequences.

2 Names and naming, by their very nature, consecrate through a process of inscription and encryption. The good and bad potential in a name is not always manifest. In this sense, giving someone a name becomes an empty gift because the name is inherently empty to the recipient but nevertheless imbued with an uncanny potential to engender, penetrate, and define the entity so named. A good name is vulnerable, and a bad name has nothing to lose except the hope to remake it. We can argue that, strictly speaking, bad+name ( 
badnam) is not the loss of a name but rather an act of renaming or at the very least the truncating of the signified. Derrida (1986) argues a name 'appropriates itself violently, harpoons, arraigns [arraisonne] what it seems to engender, penetrates, and paralyzes with one stroke [coup] the recipient thus consecrated' (Derrida in Ionescu 2011:59). But in so doing what does the name mask, or what aspects of a named entity escape naming? An entity named is an entity (re)animated. This has consequences both short and long term. And whilst a 'bad' name seemingly has 'bad' implications in the short run, badnam or badnami can serve as a detour to a 'good' name (or reclaiming a once-good name, which through the very act of reclamation stands transformed). I am neither arguing for nor interested in seeing this as a process of resurrection: after all, badnami or bad publicity can have very final, fatal consequences for certain names, and these are eventually forgotten, lost in time, or renamed and celebrated (a point to which I will return). Drawing on French thinker Jacques Derrida's philosophical oeuvre this article argues that badnami does not necessarily sound the death knell of a name; instead, the inherent vulnerability of a name makes difficult the task of predicting its social trajectory and sketching routes and detours through which a name (re)establishes a 'safe' social presence, a 'safe' social career. We can argue that this is because a name tries to represent the unnameable aspect beyond the name itself. The article shows how a 'good name' is a vulnerable, slipping mask concealing a potential 'bad name' for unnameable entities named 'science' and 'stem cells.' The movement from good to bad, from clean to soiled, from famous to infamous (badnam), reveals something crucial about the very act of (re)naming. This movement does not so much rename good as bad or bad as good as if a complete transition from one to the other is ever possible. Rather, renaming occurs when shards of imploded good names and bad names come together to consolidate a new name. This coming together conceals the symbiotic and semiotic co-production of good and bad names. Good and bad names, in other words, are admixtures from deep within the unnameable aspect of an entity struggling to manifest a new named aspect (i.e., pure good and bad entities do not exist), and very often it is this mélange that slipping masks reveal.

The article opens by explicating the theoretical and conceptual underpinning and proceeds to inspect the political anatomy of stem cells in India. A note on the ethnographic context and the research process is preceded by some empirical observations. With the burgeoning stem cell technologies in India as its empirical backdrop, the article focuses on a particular case of a stem cell facility in India offering human embryonic stem cell therapies as a site to explore the politics underscoring naming and name-calling in this promising but equally contentious scientific domain. In the final analysis I am not seeking to generalize or draw conclusions for Indian stem cell terrain as a whole; rather, I am utilizing a particular case to show how bad name reputational fears are understood in the mundane intricacies of the everyday.

\section{Badnami: save the name, except the name}

4 In his seminal essay, 'Sauf le nom,' Derrida meditates on the possibility of 'sur-naming,' supplemental naming, which takes the place of the name. Unlike a family name in English, surnom, sur-name in French, signifies a nickname. Ironically, a surname, family name, in a certain sense merely sur-names, 'nicknames,' a proper name found to be incomplete, lacking, via a heritable surname (see Dutoit 1995). Sur-name for Derrida names the unnameable because what is sur-named recedes, making the sur-name more 
than the name itself, and comes in the place of the name and thus on occasions even replaces, substituting the name. Thomas Dutoit (1995) reminds us there is no adequate translation of 'Sauf le nom.' The closest meaning in English would read 'except the name.' The literary 'save' as synonymous with 'except' allows 'save the name' to be read as doubly articulate: as 'except' the name and to literally 'save' the name, the latter finding rare and discreet mention in the text. However, the foregoing allows us to ask if surnaming is 'except' the name, whether sur-naming exception literally 'saves' the name being sur-named. More important, for the purposes of the argument here, it is worthwhile to explore whether bad+name comes to sur-name a name and in the very act establishes a new presence 'except' the name, excluding the name. If so, perhaps it is possible to imagine the receding, effacing, replaced name as 'saved' by the bad+sur+name. The (presumably good) name being sur-named as 'bad' then makes the task of (re)establishing the original name rather difficult and unnameable. As Derrida puts it, 'As if it was necessary both to save the name and to save everything except the name...as if it was necessary to lose the name in order to save what bears the name...' (1995: 58). A name names that which is beyond the name, the transcending truth that is other than the name. In this respect the name is always lacking, and this lack, 'except (save) the name,' makes naming a necessary exercise. The diversity of names, new names, old names, pseudonyms, and multiple (sur-)names circulate in a constellation that typifies neither the name nor what is named but rather beyond, in a realm where the consecrated entity remains unnameable or in a state where it is much more, ['save/except'] the name. A 'bad sur-name' is then 'except' (save) the unnameable that is not necessarily its opposite, 'good,' but rather an unnameable, unknowable, unutterable entity that is 'saved' because it cannot be named-an entity that can resurface to truncate the sur-name, replacing as well as effacing the name and what it signifies. In this sense Derrida could be understood as suggesting that 'the name hidden in its potency possesses a power of manifestation and occultation, of revelation and encrypting. What does it hide? Precisely the abyss that is enclosed within it. To open a name is to find in it not something but rather something like an abyss, the abyss as the thing in itself (2002: 213). A sur-name is the name inscribed over a bottomless abyss, a name shaped by what it seeks to cover, hide, represent, and utter. Name can be lacking because name fails to capture the essence of that which it names, which in the final analysis remains unnameable and possessing abyss-like depth.

5 In India, badnami is not just opprobrium or defamation, but also a badge of honour, at least in certain contexts. In this respect we can begin to piece together how the loss of a name, its sur-naming, can be a generative process and the starting point of renaming a set of practices that stabilize as 'good.' The valorisation of badnami or its willing embrace ( e.g., to embrace badnami or ignominy in love) is one such arena where loss helps gain a reputation of another kind that is transient and always tantalizingly close to accomplishing normative stability.

6 A name, good or bad, becomes a mask that is difficult to detach from the person/entity to whom it is attached. Following Derrida, the name, not the 'unnameable' person or entity, becomes fused with the person or entity and seizes control of the person/entity with an important caveat: the context and everyday contingency can potentially mutate to conjure the signified to mean different things. That is, from deep within the 'abyss' the unnameable can uncannily manifest and conjure a new sign. In this respect, badnami simultaneously can be a cause of shame and social opprobrium as well as an understandable momentary affliction. Lyrics of an immensely popular Bollywood song, ‘ 
Munni badnam hui darling tere liye' (Munni goes infamous [loses her reputation/name] for you o darling), are an unlikely but helpful lesson in understanding the badnami's anatomy. What we learn from Munni's predicament is that badnami is a public event with very public consequences. From Mira Bai (mystic poet circa 1498-1546) to Devdas (character from 1917 Bengali novel by Sarat Chandra Chattopadhyay) to ignominious Munni, we see a long and impressive genealogy of Indian people, fictional and real, embracing amorous badnami. Paradoxically, bad+name in these examples asserts itself as both tolerable and deplorable. For example, Munni's situation obliquely references an invisible, untarnished name slipping and soiling that is public on account of her amorous attachment to a nameless (but sur-named) 'darling.' The temporality implicit in the name's vulnerable social circulation conceals a movement from the private realm to the public, from invisible to visible, and from implicit to explicit. The consequences, whilst gendered, reveal the moral texture of a name that easily frays and disintegrates explicitly, visibly, and publicly. The mask does not so much detach from the face but rather slips, revealing in a moment of collective public gasp the frail contours of a nameless face acquiring a new (bad sur-)name, a new mask. It is in the precise moment of grappling with the mask one discovers the fragility of a name-the public disrobing and equally public enrobing of a name gesture at the possibility of recovering one's original name, mask, robe. But at the same time, the collective gasp echoes a fearful reminder that any name can slip and soil, becoming something other than what it signifies. Above all, an uncanny, lurking awareness takes hold, hinting and haunting from the unnameable, unknowable depths concealed by a name, the possibility of a new nameable aspect emerging.

7 The foregoing is a cryptic conceptual plotline of events seemingly a world away from the badnam streets invaded by 'unsupervised,' rebellious women like Mira and Munni and the occasional 'failed man,' Devdas. This is a story of the burgeoning and high-stakes field of stem cell science in India where a lone stakeholder clinician can be fighting to rescue his or her reputation for fear of badnami and ignominy (to invoke one possible meaning) in the face of regulation-commonly acknowledged as lax-and the rapidly deepening reputation of the field as a global site populated in equal measure by mavericks and mavens.

\section{Bad+name science: political anatomy of cells}

In her ground-breaking book Good Science: The Ethical Choreography of Stem Cell Research (2013), Charis Thompson describes the politics underscoring Proposition 71 and the California Stem Cell Research and Cures Act. Briefly, this proposition was enacted by California voters in 2004 to support stem cell research, most notably, embryonic stem cell research, in the state. The California Institute for Regenerative Medicine (CIRM) is a state agency brought into existence by Proposition 71. Funded by state-bond funds and backed by taxpayers for three billion over ten years and at a time when public libraries and schools across California were facing closure, the CIRM became a unique holding space for hype/hope, promise/despair, risk/reward, and intractable diseases/promissory cures.

However, the promissory value of the CIRM and its 'good name' took a big hit when local media began running stories highlighting its 'insular' and 'insider-like' way of doing business (Hiltzik 2014). The main area of contention was the CIRM's former president, Alan Trounson, who accepted a position on the board of directors of one of its highestprofile grantees, Stem Cells, Inc., on 7 July 2014, seven days after leaving the CIRM 
(Hiltzik 2014). The CIRM promised to look into the relationship between its former director and a high-profile grantee. Los Angeles Times reporter Michael Hiltzik wrote:

A well-connected company with questionable finances and a research proposal of uncertain scientific validity has received favorable treatment from the CIRM. An investigation of the relationship between the firm and the CIRM's management was placed in the hands of a law firm inextricably entwined with management and given an inappropriately narrow scope. The unanswered question burning a hole through the CIRM's credibility is whether Stem Cells, Inc. got its money because its research was promising or because it knew the right people. For most of its existence, the CIRM has been deeply hostile to outside scrutiny. The harvest is now coming in.

10 It seems the 'good name' of 'good science' is in tatters. The once 'solid name' and reputation of the CIRM and its director exploded with a shrapnel-like intensity around an emerging 'bad name.' The unfolding scandal exposes the vulnerable underbelly of 'good name/good science.' It offers a fleeting glimpse at what ensues when science fails to entwine ethics as per the norms of established choreography. This case shows not that robust scientific scrutiny is unforgiving and scrupulously ethical but rather that the quality of communication and circulation within a local environment can rapidly precipitate a prefix switch and alter the very environment in which good and bad names gestate (Bharadwaj 2014). This case also offers a peek into the unnameable manifesting from behind a seemingly good and/or bad name. We can say a name not only remains vulnerable, but also conceals an unspecified aspect that bodes forth demanding a new (sur-)name. The paradox at the heart of this scandal is that it embodies all the reputational fears bad science in global locales like India is believed to inflict on good science.

11 The emergence of stem cells in India has long been in the making. I have analysed the long genealogy of developments leading up to the birth of cellular politics in India elsewhere (Bhardwaj and Galsner 2009). Here I wish to outline ways in which state actors and private stakeholders-most notably, scientists, clinicians, journalists, and academics -make claims for regulation, relevance, and resolution. In so doing I wish to sketch out in broad strokes how commentaries on what I am calling the political anatomy of stem cells in India mirror politics of naming and name-calling within this burgeoning scientific terrain.

12 A great deal of policy-setting, journalistic, and academic ink is currently flowing on the issue of stem cell technologies in India. The stated objective of the Department of Biotechnology (DBT), as per the eleventh five-year plan of the Indian government (20072012), was to make India globally competitive by converting the country's diverse biological resources into useable products supported by a strong bio-industry base with an enhanced capability for market diffusion. The same goal is reinforced in the twelfth five-year plan (2012-2017). As early as 2005, India's union minister for science and technology proclaimed the government's intention to strengthen stem cell research in the country and support companies that followed the Good Manufacturing Practices (GMPs) per international guidelines; in this way, their products could be marketed globally (Bharadwaj 2009).

The Indian stem cell landscape is seen as an uneven terrain where a range of maverick and unethical activities dovetail scientific strides in a consensible direction. In the most recent iteration of the National Guidelines for Stem Cell Research (2013), issued by the Indian Council of Medical Research (ICMR) and the DBT, stem cells are described as not 
being part of standard care, and therefore no guidelines for therapy can be issued until efficacy is proven. Under the new dispensation no stem cell therapies can be offered to the patients except hematopoietic stem cells that are treated as a proven therapy. Stem cells can only be used in clinical trials after due approval from the Drug Controller General of India (DCGI). In tandem the DCGI is to modify Rule 21 of the Drugs and Cosmetics Act to include 'stem cell and cell-based products' as new drugs (DCGI 2013). This means clinical trials involving stem cells will require a license from the DCGI. The moves are seen as protecting the name of a promising and burgeoning field of stem cells from mavericks and unscrupulous practitioners tarnishing the image of stem cell science in India. However, these new developments are also being seen as a major hurdle in the way of medical tourism due to proposed regulatory barriers and bad name reputational fears (Jayaraman 2014).

The effort to cleanse India's reputation globally has received further fillip ever since Mr. Modi's landmark victory in the Indian general elections in May 2014. The professed aim of Mr. Modi, widely (and wildly) circulated in the media, is to turn India from a 'scam state to skill state.' The renaming (and rebranding) of India is indeed ironic given that the newly elected prime minister has struggled to cleanse his own bad name and past, as he is commonly held accountable by this opponents for the brutal religious violence that ripped through Gujarat state in India in 2002, when he was chief minister. However, by renaming India as a good, honest place to do business and culture innovative ideas, the new prime minister successfully creates new grounds for a renaming exercise that may have redemptive consequences for his own. The prime minister's flagship initiative, 'Make India,' is a big step in this direction, soliciting foreign direct investment in 25 key 'sectors' that include biotechnology, pharmaceuticals, and a notable subset: stem cells. If India is indeed a good place to do business, then the business of stem cells has to be protected, and the name of India and the stem cell terrain as a whole needs to be shielded from bad-name publicity, or badnami, that not only can have serious reputational consequences, but also result in a crisis of credibility with the potential to impact the commercial bottom line and India's ability to attract global capital inflows (see also Bharadwaj 2009).

Within academic debates-most notably, social science commentaries-the key concerns have centred around issues of governance vacuum, potential for harm, patient recruitment and patient exploitation, reputational risks, and therapeutic ambivalence (Patra and Sleeboom-Faulkner 2009; Salter 2008; Sleeboom-Faulkner \& Patra 2011, Prasad 2015). The protagonists, mainly clinicians and scientists, are portrayed as breathing easily in a governance vacuum or as manipulating a range of uncertainties in pursuit of reputation enhancement (Salter 2008; Sleeboom-Faulkner \& Patra 2008). Disgruntled patient voices are similarly co-opted to show that treatments are often no more than loot mar (cheating) in the 'name of stem cells' (Sleeboom-Faulkner and Patra 2011). Specific clinics are singled out to generalize gratuitously how gullible and desperate patients are in danger of being recruited and lured into stem cell treatments. Instances where patients report positive treatment outcomes, ambivalence, and uncertainties are shown to be unresolved. In other words, patients in these accounts are analysed and 'named' as vulnerable, hopeful, ambivalent, duped, exploited, or a combination thereof.

At one level these conclusions are underwhelming for three key reasons. First, generalizations based on specific clinics and their collaborators tell us very little about 
the scientific domain as a whole, however contested. Second, any person or patient struggling with a degenerative disorder, whether static or progressive, is highly likely to occupy an ambivalent space. Even when the therapy is seemingly working it is understandable to want more improvement, greater resolution, and to 'hope' for more. This cannot be captured to deduce that stem cell interpolations are not working as imagined or promised. Stem cells aside, even in the adjudicated terrain of so-called mainstream biomedical therapies held to be scientifically validated and purportedly safe, a straightforward resolution or outcome is seldom available. Third, much of this scholarship deploys the vocabulary of 'ethics,' 'governance,' 'experimental,' and '(un)safe' as fully formed and as taken-for-granted categories. Like the notion of name in this article, each of these concepts should be vivisected to reveal the cultural complexities animating their named presence in our professional lexicon. Instead, most social science accounts, whether unwittingly or wilfully, end up contributing to the production of a badnam 'geography of blame.'

17 A critical understanding of the stem cell terrain in India needs a more substantiated and corroborated understanding of the field. But more important, it demands that the researcher abandon his or her precarious perch on the fence and get down to the difficult analytical task of revealing how a therapy and its workings are constructed, understood, and eventually assimilated. Very often the objective fence-sitting risks looking like a tactical move to distance from a potential bad sur-name in the making. In this scene of sophisticated academic name-calling, academic reputations are also at stake: being too close or too distant from the object of study can further imbricate the value-laden terrain of social science positioning and spectating. Social scientists, like the natural scientists and clinicians they 'study,' are in the business of making a name for themselves and establishing a reputation in their chosen fields of expertise. In these accounts we find that rather than understanding the anatomy of a bad name in the making, not too dissimilarly from their natural-science and journalistic counterparts, social scientists are either actively distancing themselves from a scene of badnami or constructing one by deploying theoretical and analytical tools that produce an illusion of objective distance from a purportedly unethical 'scene' under scrutiny. In my own work, this has been a source of much reflection and critical self-appraisal, a source of constant questioning of my tools, techniques, and ability to understand and explain notions of therapy, efficacy, harm, cure, disease, and the politics underscoring these troubled relationships (e.g., Bharadwaj 2013). However, new emerging insights are instigating refreshing new perspectives on the vexed question of stem cell governance and asking pertinent questions such as 'what does the effort to debate and govern stem cell therapy conceal as well as reveal about India's engagement with biomedicine?' (Tiwari \& Ramana 2014: 415). At this juncture it seems very likely that as the conversation evolves the terrain will move towards a more nuanced and reflexive engagement in naming the stem cell terrain, in keeping with its dynamic nature.

\section{The ethnographic backdrop}

18 My ethnographic focus is a small clinical facility in New Delhi, a site where I have conducted stem cell fieldwork since 2002. The small clinical facility is an outlier to the extent that it is a marginal player in the high-stakes field of stem cell science in India and around the globe. However, the clinic offers a compelling illustration of the politics of 
making bad and good names and forms part of a multi-sited ethnographic project. In this article I am seeking to trace the metaphors of badnam and badnami through multiple terrains to piece together a fragment seemingly scattered in disparate domains ranging from local and global bio-scientific controversies to multi-media reports, which Marcus (1995) in his original formulation describes as one of the most important sites for cultivating a fully formed multi-sited ethnographic practice, to everyday ethnographic encounters and conversations in mundane settings. Largely, this article draws on intensive and longitudinal participant observation in the previously mentioned clinical facility and on fieldwork in other parts of India as well as local and global media reports, along with interviews and daily conversations with the clinic director. This ongoing research is examining stem cell technologies in India and the contested nature of stem cell science in the ethical as well as regulatory landscape in India. The very act of naming and separating good science from bad science appears to drive these developments. A multiplicity of actors-from the Indian state to private stem cell start-ups as well as local and global patients in search of stem cell therapies-have come to have a vested interest in the 'correct and fair naming' of the Indian stem cell terrain. The global bio-scientific adjudications and pronouncements on what constitutes good-name science have only exacerbated the contest on naming the unnameable depths of scientific and cellular therapeutic potential (Bharadwaj 2013a, 2013c). Interactions with the growing number of Indian and foreign-treatment seekers are yielding insights into the contingent nature of healing, agency, and wider reaction to hESC-based therapies. Treatment seekers from different parts of the world reported that the professional and biomedical response in their countries of origin was to (sur-)name them as gullible dupes being manipulated by guileful stem cell mavericks in India. The good/gullible and bad/guileful naming of players in this infinitely complex field of global travel for stem cell therapies reveals just another layer in the (re)naming practices haunting the emerging stem cell terrain in India (see Bharadwaj 2012, 2013c).

In this article all names are kept anonymous to preserve confidentiality, as per the ethical protocols at the Graduate Institute of International and Development Studies, Geneva, and the European FP7 framework guidelines. However, where interviewees expressly asked to be identified by their first names no anonymity was attempted. Also, in accordance with prevailing institutional and European Commission FP7 framework ethical injunctions, I have attempted to keep the identity of the clinic or the clinic director anonymous. However, I am well aware I may not succeed, as both feature prominently in global-media debates and regulatory, as well as scientific, public spheres (see Bharadwaj \& Glasner 2009). The very act of sur-naming research-participant and related entities such as clinic names creates ironic but creative solutions involving names and what they are held to reveal, mask, and make explicit if uttered and made unsafe through the modality of naming. The bureaucratic logic that seeks to 'save the name' via pseudonym sur-naming echoes what Das describes (2015) as a kavacha (shield name), which protects a child from ghosts, who are cunningly deluded into thinking the child's public name is the real name (which is only known to the parents). The bureaucratic shielding of the research subject from potential harmful exposure creates conditions where only the researcher knows the real, asli, name (see Saria 2015). In other words, everything 'except' the name becomes nameable in order to 'save the name.' 


\section{Badnam science}

My ongoing conversation with the clinic director began in 2002. Throughout my interactions she has shown reflexive awareness about the source of criticism haunting her clinical work, which is in danger should the Indian lawmakers ratify the proposed legislation demanding DCGI-approved clinical trials for stem cell therapies. In the first phase of my interactions (2002-2005) we discussed the promise of stem cells and the challenges in proving safety and efficacy. This was at a time when human embryonic stem cells were being 'named' globally as the most potent source of regeneration. The second phase (2005-2010) moved the conversation towards clinical and therapeutic work; this was also when international criticism and peer outrage began to gain prominence and become consolidated in the public domain in India and beyond. The name-calling from peers and journalists alike made her reflect and focus closely on her location in India and the potential prejudice in the Euro-American terrain towards biomedical breakthroughs in distant parts of the globe (e.g., Guardian 2005). For example, in 2008 a team of British scientists discovered antibiotic-resistant bacteria and proceeded to name it New Delhi Metallo-beta-lactamase-1 (NDM-1). By about 2010, the naming controversy had spread to India and was heavily criticized by the Indian state and the scientific community alike. The NDM-1 team leader, Dr. Walsh, advised people to 'think long and hard' before undergoing treatment in Indian hospitals (Narayan 2010). As this controversy was unfolding the clinic director saw this as just another example of bad-name politics on a global scale:

You take the issue of the super bug they have accused, they have done a research and they have published in the Lancet. Now I will question the Lancet editor as to why he allowed that to happen if he is supposed to be the editor of the most reputable peer-reviewed journal, how did he allow an article with 35 patients to be published? They are saying there is a new Delhi super bug, they named it after my city, and that 35 patients came in and got the super bug, so don't go to India for surgery; how can you know that? Did you have proof that this patient did not carry this bug into India and went back with it? Number two, how can you pass such a statement in a journal, then what do you say, you say that this a Euro-American kind of bias, this is the biggest proof I think of as to how they don't want anyone else's medical, scientific breakthroughs or services to flourish.

The naming and name-calling in this controversy was unprecedented, as the Lancet, which published the breakthrough, openly accused the Indian government of 'suppressing' the truth about the presence of drug-resistant bacteria in Delhi's public water system (Indian Express 2011). The controversy, however, only reinforced the fear of well-orchestrated badnami and its ability to truncate names and indelibly attach itself to people and places.

The third and ongoing phase of my conversation with the clinic director (2010-2015) hybridized the focus of the earlier phases, as the clinic director began reflecting on a continued failure to communicate her work to her peers and her location in a constructed 'geography of blame.' She felt both factors were offering her detractors the ammunition to tarnish her reputation and name. For example, since 2011 she has believed that the media name-calling has resulted in an inability to publish papers in scientific journals. She remains hopeful that publishing her data will lead to a new sur-name, quite possibly a good cleansed name, vindicating her work thus far. When asked in 2013 whether she

South Asia Multidisciplinary Academic Journal, 12 | 2015 
thought ignorance and the fear of the unknown were brought on by a lack of published data, she concurred: 'Absolutely! Come on, Third World country, India, stem cells, we can't even handle our traffic, I understand, I get that, I get that, they are sceptical. At the same time I know my thing is working.' In her assessment, publishing data was only part of the solution. The location of her work was also largely badnam. I often probed deeper when she referenced an unknown 'they' as the source of opprobrium and bad name:

$\mathrm{AB}$ : Who are the 'they'?

CD: 'They,' let's say CNN, for example, their choice of patients, choice of words, but they give me a one-hour documentary, and then they have the cheek to come to my country, my city, and my everything and have an entire discussion on my work without inviting me, I mean that shows me I am important, that's wonderful! Let them criticize me.

In 2012, CNN had caused a small ripple with their documentary on her stem cell therapies. I had a ringside view to the five days of shooting at the clinic and the series of interviews with the clinic director as well as many of the in-patients (I later learned they interviewed patients in the US over several months). However, many of these patients did not make it to the final cut, and in the words of the clinic director, 'they chose to speak to a patient who had improved but could not speak for himself, with divorcing parents who were not speaking to each other.' The documentary had deployed the tell-tale signs of an Orientalizing trope and some glaring factual inaccuracies. For example, the voice-over describes how disabled patients, in this 'less than luxurious facility,' were forced to use toilets down the corridor. However, all patient rooms have attached disabled-friendly bathrooms. The clinic director later quipped that truthful narrative would have done little for the bad-name science drama CNN was seeking to relay to the world.

On 14 August 2012 CNN screened the documentary in the India International Centre in New Delhi. The screening was for an invited audience, but the clinic director was not invited. However, as she later recalled, 'unfortunately I was there.'

AB: How did you get there?

$\mathrm{CD}$ : I was there for another programme.

$\mathrm{AB}$ : What programme?

CD: A birthday party. (Laughs)

CD: People recognized me in the toilet: 'Hey, your program is up there.' I said, 'Hey, let me go up there!'

AB: You're joking, you're making this up?

CD: No I am not, I never joke, and I never speak an untruth. I walked in, I sat down, and they were towards the end of the screening, and then they got up and asked, Yes, are there any comments, so I stood up and said, 'As this programme is about me and I have not been invited and I am busy, I need to say a few words,' and I spoke a few words to the audience.

$\mathrm{AB}$ : And what was the reaction?

$\mathrm{CD}$ : The audience thought it was a very one-sided program and they [CNN] were out to get me. In fact I got few patients from that audience thereafter! And then the CNN chief I think was very kind to ask whether he could come back again, and I said you're most welcome anytime, [but] speak the truth!

The growing media interest in her work and the very public naming and renaming of the clinic director had become an established trend by 2012. If anything the name-calling and trial by media was getting shrill. The Guardian story that set the ball rolling in 2005 cited experts who unanimously concluded that her stem cell story was 'highly implausible and frankly downright dangerous. If the Indian government wants to promote stem cell research, then it needs to seriously look at regulation of these doctors and if necessary 
close them down.' Similarly, a host of media reports alluded to the clinic director as a 'dangerous maverick' (see Sky News 2006, 2007; Telegraph 2007, 2008; Fitzpatrick \& Griffin 2012). The conclusion was unanimous that such maverick clinicians were bringing the science of stem cell into disrepute and giving scientists everywhere a bad name. The clinic director, however, has repeatedly hit back, arguing that her name is being dragged through the mud and despite dramatic reversals in several patients, she is unfairly ostracized and her name wilfully maligned. Asked whether she felt largely discredited she responded, 'No, I never feel discredited. My patients give me all the credit. I don't need any outside stamp of approval for feeling good about my work.'

Many clinicians and stem cell practitioners around India see patients and patient testimonies as a natural corrective. A disgruntled or harmed patient can result in serious badnami. A negative testimonial also instils a fear of losing patients as well as losing face. The consequences are both reputational and financial. Bad+name is not good for business. For example, Forbes magazine articulated these bad-name reputational fears most explicitly in a 2013 article, when it claimed that 'fearing that unscrupulous use may hijack this promising field [stem cells in India], stakeholders are racing to regulate its applications.' The main fear articulated in the news piece was that of reputation, a fear of losing credibility. By citing several 'expert' testimonials, the piece cautions how 'between the huge unmet human need for treatment of incurable diseases and the hype around the possibilities of these therapies on one side, and the opportunistic and unscrupulous physicians exploiting the situation on the other, good science [emphasis added] struggles to move forward...' (Forbes 2013).

A closer reading of the concerns in this article reveals the financial potential of stem cell markets globally and the Indian potential stalked by concerns about poor reputation. The article (guess)timates the global potential as being around 1.2 billion in 2012 and growing at $30 \%$ to reach 16 billion by 2017, 600 million of which would be the Indian-market segment. The article valorises 'experts' it cites as 'rooted in science' against the unscrupulous elements that by implication only feign scientific know-how. Making a strong pitch for the commercial potential of stem cells, the article cites Minger, who moved from King's College London to GE Healthcare, as 'he thought the time was right for commercialization,' arguing that the international marketplace needs regulation so that 'the reputation of regenerative medicine is not compromised.' The vulnerable (sur-)name of an unnameable entity, 'stem cell science,' continues to oscillate between the good- and bad-named protagonists. What journalistic ventures such as the Forbes article discussed previously and the larger scientific establishment fail to capture in any meaningful way is that names are not just vulnerable, but also seldom permanent. Reputational fears of good going bad or bad going good remain an inadequate possibility because the unnameable aspect of an entity or person is adept at manifesting the unutterable concealed by a (sur-)name.

\section{A bad name by another name}

It's centrifuged blood: that's all. They are drawing blood from patients, centrifuging it in a lab in Bangalore for six to seven thousand rupees and injecting it back into patients for two lakh rupees. They do this, and stem cells get badnam. If this doesn't stop, stem cells will become a badnam science, you know? People simply don't care; it's just another get rich quick scheme, never mind the damage to the reputation, never mind the badnami. 
was just another Wednesday afternoon as the clinic director and I sipped tea in her office. The outpatient rush had subsided, and we discussed the complexities of the Indian stem cell terrain. Her criticism of 'rogue' stem cell clinics in India was ironically paraphrasing castigations she routinely received in the local and global media. The outburst was also ironic, as the revised ICMR-DBT (2013) guidelines had singled out hematopoietic stem cells as permissible. It was clear from the guidelines that 'minimal manipulation' of stem cells via centrifuging, so long as under aseptic, GMP and GLP (good laboratory practice) conditions, did not need Institutional Committee for Stem Cell Research oversight nor DCGI approval. The bureaucratic and bio-scientific renaming of centrifuged blood as stem cells was another fascinating development underscoring the emergence of politics of (re)naming biogenetic artefacts. After all, clinical use of entities such as bone marrow is decades old and yet renaming bone marrow as stem cells recasts something old and familiar into a new and strange entity needing robust governance.

That a range of mavericks and mavens populate the stem cell terrain in India is beyond dispute. However, local and global media hyperbolae often paint the Indian terrain as uniformly maverick. This deepening badnami is cause for much worry, as several clinicians working on the forefront of stem cell therapies in India resist standardized 'good science' prescriptions emanating from the 'West' (Bharadwaj 2013a, 2013b). Ironically this resistance only reproduces tropic templates of 'good and bad name science' in a rapidly globalizing biotechnology. In other words, in this global scene any entity can acquire a bad name: the science of stem cells (a fear routinely invoked by 'Western experts'), individual clinicians (in India and beyond), and cellular form itself (as inherently dangerous). At every level, names and reputations appear vulnerable, precariously close to going bad.

The everyday clinical encounters with stem cells in a reputational and bad-name vacuum are far from straightforward. For example, as noted elsewhere (Bharadwaj 2013b), on one of my regular visits to the clinic I witnessed a chronic spinal-cord-injury patient move his toes and lift both his legs. The patient had moved his legs for the first time in fifteen years, a dramatic moment for him and the clinic director. The clinic director appeared vindicated, as if the patient, by moving his legs, had validated the therapeutic efficacy of stem cells. Her excitement was tempered by the fact that this breakthrough would count for nothing. Resigned but equally elated she quipped, 'This is headline news; if this were happening in America or Europe, forget lifting his leg. Even if he were moving his toes, they would be hailing it as a breakthrough of the century.' Smiling, she continued, 'But wrong place. It is not meant to be happening here, right?' The isolation and ostracism of a bad name made it possible for her to imagine the likely outcome and quietly accept it. It is as if a bad name renders worthless all achievements; name and place conflate and conspire to produce a favourable outcome with an unfavourable name. It is interesting to note that many patients absorb the stigma of badnam science. It is as if the very act of embracing a therapeutic modality embedded in the badnam science renders them gullible, desperate, and duped. That is to say badnami comes to attach itself to a patient's body and erases the individual to an extent to produce a cohort that has lost all sense of judgment, reasoning, and the will to exercise caution (Bharadwaj 2013b). Despite the long, tireless history of researching stem cells and clinical facilities around the globe and in India, informal participation and patient-support networks are similarly erased from scientific and journalistic assessments (Bharadwaj 2013b). The surrender of reason and surrender 
of one's corporeality is conflated. The bad-name science is bestowed with dark powers that can ensnare while incanting a state of collective bad faith.

It is crucial to understand that badnami is a localized event that can reverberate much further. In the present case, aspersions of badnam science are localized within a scientific polity that is "consensually constructed by scientists and implemented from within a specific view of science that sees in its putative modality all the necessary conditions to normatively support, ideologically discipline, and structurally contain the experiment' (Bharadwaj 2013c: 86). The global politics of science see this context as fundamental to cordoning off adjudicated spaces in which only a consensible rule ordained 'good' name science could thrive. The notion of ethics is as standardized as the fantasy body of a goodname science that can be globalized cross-culturally to mean the same thing. However, on a number of occasions through the course of my daily conversations with the clinic director I learned that ethics were not so much variable or in some essentialist sense contingent or relative to particular cultures but rather universal in ways that bureaucratized ethics embedded in bioethical discourse couldn't possibly accommodate. Through the course of our conversations over the years the clinic director has repeatedly maintained how 'it's not that I am unethical; I am perfectly ethical, but my ethical work is seldom recognized as such.' And yet, I could not understand the resistance towards standardized ethical protocols and peer-endorsed practice that would have let the clinic off the hook without the attendant inconvenience of acquiring a bad name. However, one winter evening in 2014, a chance conversation with the director offered an interesting peek into the fascinating world of stem cell science purportedly going badnam when she said:

We never opted for a clinical trial because we are against giving placebos. The patient is the control because there is chronicity, and it is not fair to treat a patient with a placebo, especially if an ALS [Amyotrophic lateral sclerosis] patient is coming to you who is going down every day. The institutional ethics committee [made the] decision a very long time ago that there [would] be no placebo, as it is against our ethics; we can't stand back and watch an ALS or motor-neuron disease patient rapidly worsen and die; it is against our ethics.

32 At first I understood this outburst as a pursuit of 'local good' circumscribed by contingent ethics that are produced in relation to sensibilities populating the everyday engagement with life. It seemed that from the ivory tower of big, baroque science, badnam-science interpolations into human biology appear dangerous, destructive, and unruly. However, a closer reading reveals a wilful and willing embrace of badnami. The ethics of good-name science is easy to accomplish, but the daily struggles of terminal and incurable patients made it impossible for the clinic to stage-manage its good name.

I have followed ALS patients since 2012 and am very aware of how viciously the disease attacks stem cell insertions. Constantly beating back a progressive and aggressive condition is the only viable recourse. I met Warner (pseudonym) on his first-ever visit to the clinic in May 2013. In Germany, where he was first diagnosed in early 2013 with ALS, he was given fewer than three months to live. A qualified surgeon who understands biomedical prognostications, he looked for alternatives to fight the rapid progression of ALS. A colleague who had patients return to Germany after successful stem cell treatments in the clinical facility in New Delhi suggested he try embryonic stem cell treatment.

34 I first met Warner when in the clinic director's consultation room. He was trembling, and his hands and arms were shaking with festiculations. The quivering skin and muscle 
spasms were incessant, and his speech was slow and on occasions muffled. Through the course of the treatment at the clinic I witnessed his body stabilise to the point where one had to peer closely at his skin to find spasmodic activity such as continuous twitching. By the time he returned, Warner was very stable, felt immensely energetic, and walked unassisted.

In May 2014, exactly a year after his first treatment, I flew to Berlin to meet him. It was a sunny May morning as I rang the doorbell of his suburban home ensconced in a meticulously planted garden. Much to my surprise, he answered the door and ushered me into the front room where his in-laws together with his wife greeted me with homemade cake and tea. Warner updated me on his progress. He was continuing to get stronger and could even work part time. And since the debilitating condition fought back his recovery narrative was punctuated by stories of setbacks and extreme elation as his body fought back. He shared his 'peak flow' graph that meticulously tracked his daily progress through the months of March, April, and May. The upward trajectory of his progress was heartening. A little later that evening we all left his home and walked two blocks to a neighbourhood restaurant for dinner. The whole evening was spent talking and laughing as Warner enjoyed his food and a few beers-not once did he balk or complain of exhaustion. A little later that year Warner returned to Delhi for his 'top-up dose,' and after a few months of sustained treatment he returned in early 2015. He often told me how he knows when it is time to go to India for a top-up and likened his daily struggle with ALS as a battle where he needs to reinforce his defences with embryonic stem cells. When asked whether he was among the lucky few who survive ALS with little or minimal medical treatment, Warner confronted me with accumulating evidence that showed a clear correlation between the time lapsed since stem cell insertions and his worsening condition as well as a subsequent pick up in progress after stem cell interpolations. He often says he doesn't need to convince anyone; he knew he was getting better but had to go on fighting.

36 As many millions around the globe perish each year awaiting ethically produced translational research, the reputational fears of good-name science barely conceal the 'ethical violence' that does little to tarnish its name. It takes a giant such as the CRIM to veer off the ethical track for a bad name to become a haunting presence. However, in the case of the Indian clinic, and bad (sur-)named science, an unnameable good appears to be gestating in prolonging ALS-afflicted lives. Whether it will precipitate a (sur-)name change is another matter altogether. But, as in the case of the CRIM, the vulnerable name conceals an unspecified aspect that comes forth demanding a new (sur-)name.

\section{Conclusion}

37 A bad name is a sur-name, that is, except/save an unnameable, unspecified aspect that survives and resurrects to truncate what a sur-name, good or bad, can mean in a given context. The (sur)names are uncanny and enchantment par excellence. They can trick and dissimulate (Das 2015); precipitate contests overs real/asli and unreal/nakli names (Saria 2015) or, as in this case, render names impermanently (sur-)named as bad or good. The negative theology implicit in Derrida's argument makes one confront the 'open texture of a name,' that is, a multiplicity of names engendering a multiplicity of possibilities, which Das expertly describes in this collection. For Derrida, God is the name of a 'bottomless collapse,' of 'an endless desertification of language' (1995: 55-56). The 
'referential transcendence of language,' according to Derrida, is to say God is beyond his images, beyond the idol, or beyond what is said, seen, or known of him. Just as negative theology 'refuses,' 'denies,' and 'rejects' all the 'inadequate attributions' (1995: 69), a name, good or bad, remains at best an 'inadequate attribution.' A negative procedure allows us to grapple with everything except the name that keeps the possibility of renaming safe and a procedure for saving the name ever present. In other words, good or bad names exist, 'save/except' the unnameable aspects beyond the name. This unique quality inhered in a name leaves open ended the possibility of canny and uncanny manifestations from beyond the name to impact and truncate a name.

In India it is widely recognized that the world's second and India's first IVF baby was born sixty-seven days after the birth of Louise Brown, on 25 July 1978. On 3 October 1978, Dr. Subhas Mukherjee announced the birth of Durga in Calcutta. Dr. Mukherjee is credited with many firsts in the world of reproductive and infertility medicine, including the use of gonadotropins for ovarian stimulation, a transvaginal route for harvesting oocytes, and the freezing and thawing of human embryos before transferring them to the uterus. Although he published a short note on his work in the Indian Journal of Cryogenics, his claim was largely discredited. Deprived of any opportunity to pursue his research, public humiliation and ridicule from his peers eventually resulted in Mukherjee taking his own life in 1981. The badnam 'quack' was to remain unrecognized until the late 1990s, when his diaries, papers, and research data were resurrected. The circumstances leading to Mukherjee's suicide and the politics behind his subsequent reinstatement as the 'scientific father' of India's first and the world's second 'test-tube baby' are analysed elsewhere (Bharadwaj 2002). Here I remind myself that bad name and badnami can have dangerous consequences. Mukerjee's name is now purified to the extent that he is hailed, by the very establishment that drove him to suicide, as the scientific father of the first test-tube baby in India and the second in the world. Names can be restored, but restoration is not the same as re-establishing the previous one. Salvaging a bad name entails renaming. Nothing is salvaged, reclaimed, or regained. The new name is a new start, a precarious journey of a vulnerable new name.

The story of stem cells in India is similarly replete with ironies. The 'pro-cure' rhetoric of 'good (sur-)named/good science' that enabled the CIRM in the United States to come into existence is seemingly bearing fruit in distant 'bad+sur+named' Indian clinics, where stem cell therapies are thriving and in some quarters producing results. Another irony is centred on the need for external validation and credibility, as shown by the clinic director cited previously as saying, 'My patients give me all the credit. I don't need any outside stamp of approval.' The global-media reports are replete with expert testimonials either condemning the clinic or doubting the reported outcomes whilst grudgingly reporting breakthroughs that appear to be making a difference.

The Forbes report discussed previously had similarly criticized the clinic by stating 'personal testimonies are not scientific data, and this distinction needs to be made when reporting these stories [of treatment breakthroughs] [...] some clinics ['naming' the clinic and the clinic director] are beginning to understand this...' (2013). What the Forbes report and several other journalistic accounts failed to grasp was that the clinic had steadfastly opposed scientific publications in peer-reviewed journals on legal advice to protect its pending patent application, a somewhat unusual but not uncommon practice across the globe (see Bharadwaj 2013a). This refusal, however, further cemented the bad-name credentials of the clinic, and many scientific and journalistic quarters wilfully 
(mis)understood this as further evidence of the clinic's suspect and poor scientific practice. From 2013 to 2014, the clinic was granted 65 patents around the globe. As if on cue, the clinic director began submitting several articles detailing everything from the science behind the stem cell interpolations to treatment protocol and systematic data on treatment outcomes broken down by terminally progressive and incurable static disorders for peer review in international scientific journals. At last count seventeen articles have appeared in peer-reviewed journals. The bold and radical departure from a peer-endorsed modality of stem cell procurement, culture, and administration has now become validated, but the clinic director is still waiting for a verdict on her attempt to cross an important passage point, peer-reviewed journal articles, and whether this will result in a landmark scientific publication. As these articles circulate and are scrutinized the prefix may switch from bad to good. And it is not long before the curtain goes up on the penultimate scene in this bad-name drama.

\section{BIBLIOGRAPHY}

Bharadwaj, Aditya (2002) 'Conception Politics: Medical Egos, Media Spotlights, and the Contest Over Test-tube Firsts in India', in Marcia Inhorn \& Frank Vanbalen (ed.), Infertility Around the Globe, Berkeley: University of California Press, pp. 315-33.

Bharadwaj, Aditya (2012) 'Enculturating Cells: Anthropology, Substance, and Science of Stem Cells', Annual Review of Anthropology, 41, pp. 303-17.

Bharadwaj, Aditya (2013a) 'Ethic of Consensibility, Subaltern Ethicality: The Clinical Application of Embryonic Stem Cells in India', BioSocieties, 8(1), pp. 25-40.

Bharadwaj, Aditya (2013b) ‘Subaltern Biology? Local Biologies, Indian Odysseys, and the Pursuit of Human Embryonic Stem Cell Therapies', Medical Anthropology, 32(4), pp. 359-73.

Bharadwaj, Aditya (2013c) 'Experimental Subjectification: The Pursuit of Human Embryonic Stem Cells in India', Ethnos, 79(1), pp. 84-107.

Bharadwaj, Aditya (2014) 'Episcience: The Biological and Epistemic Plasticity of Stem Cells in India', paper presented in the annual conference for the Society for Social Studies of Science (4S), Buenos Aires, 23/08/2014.

Bharadwaj, Aditya; Glasner, Peter (2009) Local Cells, Global Science: The Proliferation of Stem Cell Technologies in India, London: Routledge.

Das, Veena (2015) 'Naming, Aspect Dawning and the Physiognomy of Words', SAMAJ, 12.

DCGI (2013) 'Guidance Document for Regulatory Approvals of Stem Cell and Cell Based Products (SCCPs)', Document No. STEM CELL AND CELL BASED PRODUCTS (SCCPs)/SPS/2013-001 Version: 004, 30 Dec.

Derrida, Jacques (1986) Glas, John Leavey, Jr., and Richard Rand (trans.), Lincoln \& London: University of Nebraska Press. 
Derrida, Jacques (1995) On the Name, Thomas Dutoit (ed.), David Wood, John Leavey, Jr., \& Ian McLeod (trans.), Stanford: Stanford University Press.

Derrida, Jacques (2002) Acts of Religion, New York: Routledge.

Dutoit, Thomas (1995) Translating the Name? In On the Name, Stanford: Stanford University Press.

Fitzpatrick, David; Griffin, Drew (2012) 'Family Hangs Hope for Boy on Unproven Therapy in India', CNN Special Investigations Unit, 21 May, URL: http://www.cnn.co.uk/2012/05/19/health/ embryonic-stem-cell-therapy/index.html.

Forbes (2013) ‘Stem Cell Industry: The Battle Within', Forbes.com, 12 February, URL: http:// forbesindia.com/article/real-issue/stem-cells-industry-the-battle-within/34697/0.

Franklin, Sarah (1990) 'Deconstructing 'Desperateness': The Social Construction of Infertility in Popular Representations of New Reproductive Technologies', in Maureen McNeil, Ian Varcoe \& Steven Yearley (eds.), The New Reproductive Technologies, London: Macmillan, pp. 200-29.

The Guardian (2005) 'Row Over Doctor's' Miracle Cures”, TheGuardian.com, 18 November, URL: http://www.theguardian.com/science/2005/nov/18/stemcells.controversiesinscience.

Hiltzik, Michael (2014) 'California's Stem Cell Scandal Gets Worse', LATimes.com, 25 July, URL: http://www.latimes.com/business/hiltzik/la-fi-mh-californias-stem-cell-scandal-20140725column.html\#page=1.

ICMR-DBT (2013) ‘Guidelines for Stem Cell Research', Indian Council of Medical Research, URL: http://icmr.nic.in/guidelines/NGSCR\%202013.pdf.

Ionescu, Arleen (2011) 'Pas-de-noms/ Plus de noms', Word and Text, 1(1), pp. 59-69.

Indian Express (2011) 'India 'Suppressing' Truth about Presence of NDM-I, says Lancet', Sun Apr 10, URL: http://archive.indianexpress.com/news/india-supressing-truth-about-presence-ofndmi-says-lancet/774209/0.

Jayaraman, K.S. (2014) 'Unproven stem cell therapy banned: Companies call the move 'illogical' and say it could hurt medical tourism', URL: http://www.natureasia.com/en/nindia/ article/10.1038/nindia.2014.39.

Marcus, G. E. (1995) 'Ethnography in/of the World System: The Emergence of Multi-Sited Ethnography', Annual Review of Anthropology, 24, pp. 95-117.

Narayan, Pushpa (2010) ‘India Trashes ‘Superbug' Report, Says it's Doctored', Times of India, URL: http://timesofindia.indiatimes.com/india/India-trashes-superbug-report-says-its-doctored/ articleshow/6301982.cms.

Patra, P. K.; Sleeboom-Faulkner, M. (2009) 'Bionetworking: Experimental Stem Cell Therapy and Patient Recruitment in India', Anthropology \& Medicine, 16(2), pp. 147-63.

Prasad, Amit (2015) 'Ambivalent Journeys of Hope: Embryonic Stem Cell Therapy in a Clinic in India', Health, 19(2), pp. 137-15.

Salter, B (2008) 'Governing Stem Cell Science in China and India: Emerging Economies and the Global Politics of Innovation', New Genetics and Society, 27(2), pp. 145-59.

Saria, Vaibhav (2015) ‘To Be Some Other Name: The Naming Games that Hijras Play', SAMAJ, 12. Sky News (2006) ‘Stem Cell Miracles’, 23 January, no access information available.

Sky News (2007) ‘Miracle Stem Cell Cure?’ 13 April, no access information available. 
Sleeboom-Faulkner, M.; Patra, P. K. (2008) 'The Bioethical Vacuum: National Policies on Human Embryonic Stem Cell Research in India and China', Journal of International Biotechnology Law, 5(6), pp. 221-34.

Sleeboom-Faulkner, M.; Patra, P. K. (2011) 'Experimental Stem Cell Therapy: Biohierarchies and Bionetworking in Japan and India', Social Studies of Science, 41(5), pp. 645-66.

The Telegraph (2007) ‘Delhi Stem Cell Jabs “Help Woman Walk Again”, telegraph.co.uk, 14 April, URL: http://www.telegraph.co.uk/news/worldnews/1548589/Delhi-stem-cell-jabs-help-womanwalk-again.html.

The Telegraph (2008) ‘Australian Man 'Recovers' After Stem Cell Treatment', telegraph.co.uk, 27 May, URL: http://www.telegraph.co.uk/news/worldnews/australiaandthepacific/ australia/2036414/Australian-man-recovers-after-stem-cell-treatment.html.

Tiwari, Shashank; Raman, Sujatha (2014) 'Governing Stem Cell Therapy in India: Regulatory Vacuum or Jurisdictional Ambiguity?’ New Genetics and Society, 33(4), pp. 413-33.

Thompson, Charis (2013) Good Science: The Ethical Choreography of Stem Cell Research, Cambridge, Massachusetts: The MIT Press.

\section{ABSTRACTS}

The range of the implicit meanings of badnam (bad name) stop short of unpacking the complexity underscoring the implied soiling and spoiling of 'name': the crucible of reputation, honour, and dignity. What happens when diverse stakeholders working in the burgeoning and high-stakes field of stem cell science in India fear badnami, ignominy (to invoke one possible meaning), in the context of a regulatory flux and fears of rapidly deepening reputation of the field as a maverick site for stem cell research and clinical application? Drawing on longitudinal research mapping the stem cell technology terrain in India and the changing fortunes of a small clinical facility, this article shows how the spectre of 'spoilt name' (or badnami) haunts professional narratives and how scientific validation, national honour, economic viability, therapeutic efficacy, and safety come to reside in the 'name.' The article conceptualizes 'name' as inherently vulnerable and examines its threatened status to highlight the unnameable, unspecified aspect that survives demanding a new name despite the ethics and politics implicit in naming and 'name-calling.'

\section{INDEX}

Keywords: stem cells, India, bad name, science, badnam

\section{AUTHOR}

\section{ADITYA BHARADWAJ}

Research Professor, Anthropology and Sociology of Development, Graduate Institute of International and Development Studies, Geneva 